\title{
Opinions of Middle School Students on the Justice Concept within the Framework of Social Studies Education
}

\author{
Sibel Oğuz Haçat ${ }^{1}$ \\ ${ }^{1}$ Kastamonu University, Faculty of Education, Department of Social Studies, Kastamonu/Turkey \\ Correspondence: Sibel Oğuz Haçat, Kastamonu University, Faculty of Education, Department of Social Studies, \\ Kastamonu/Turkey.
}

Received: March 23, 2018

Accepted: April 5, 2018

Online Published: April 10, 2018

doi:10.5430/ijhe.v7n2p210

URL: https://doi.org/10.5430/ijhe.v7n2p210

\begin{abstract}
The aim of this study is to reveal the opinions of middle school students about the justice concept. The study was carried out in accordance with the document review technique, which is one of the qualitative research methods. The study group consists of 82 students attend in 7th grade receiving education at a middle school in the city of Kastamonu in the school year 2016-2017. Data was obtained using semi-structured interviews consisting of open-ended questions. This data was interpreted using content analysis and by way of coding. Middle school students' opinions on justice concept are represented in 8 different categories and they use 7 different sayings relating to the justice concept. Whereas the justice concept is most often explained as "Rightfulness", it is least often conceived as "Abstinence from Committing Crimes". It is observed that the saying "Justice can do what swords cannot" is used by middle school students most often, and the saying "No merit can be more noble than justice" least often. In light of this information, middle school students can be provided with environments in which they can internalize the justice concept. Furthermore, results about justice can be drawn when its content is broadened. We can do scientific study about justice in more detail by increasing sample group.
\end{abstract}

Keywords: justice, social sciences, middle school students

\section{Introduction}

Justice is among the most important concepts discussed by philosophers and lawyers since ancient times (Kaylhan, 2008: 45). There is no full consensus among thinkers about the definition of justice. Whereas for some people justice is giving as much as you take, it is inequality itself for others (Öktem, 1983: 51). Under the surface of the failure to identify justice concept explicitly, its remaining ambiguity lies in its being a value judgment. Justice increases in value and its meaning is determined with both ethical and legal value judgments. In the Turkish Language Association's dictionary, on the other hand, justice is defined as ensuring the exercise of rights conferred by laws on everybody, compliance with rules, rights and laws, looking after people's rights, giving everybody that which they deserve.

Justice, which is the object of legal rules, is, in fact, an idea, a collective idea not of one specific person but of all the people living in society. The idea of justice has a place in the lives of societies. This idea guides individuals to struggle for causes they consider rightful (Güriz, 2012). Justice confronts us as an ideal that needs to be achieved by law. When society changes, the ideal also changes. Therefore, the law has to adapt itself to changing ideals. Thus, the idea of justice or ideal law uncovers a social dynamism (Aslan, Korkutay, Şenyüz, \& Deliveli, 2011). These examples relating to life in society and intergovernmental relations prove that the idea of justice is an effective and living power (Güriz, 2012). In other words, in a society that is devoid of justice, people cannot live in peace (Atay, 2016).

Justice carries different meanings from the point of view of the state or the individual. From the point of view of the state, justice is conferring rights upon its citizens and loading them with equal charges without preferring certain people or groups to others while legislating and distributing rights and duties. From the point of view of individuals, on the other hand, justice refers to citizens' obligation to observe each other's rights all the way (Yavuz, Duman, \& Karakaya, 2016). Justice in the most general sense is the moral principle prescribing the conferral of rights to each holder. This principle is the reason for the formation of law and the relative goal thereof (Atay, 2016). Some people have categorized the justice concept as commutative justice, distributive justice, fairness, or social justice. 
Commutative justice refers to the necessity of equality and equal treatment of all before the law regardless of their religion, language, race, sect, or gender as is specified in the law that was introduced into our constitution as Article 10 (Cansel, Özel, Yüksel, \& Büyüktanır, 2012). Fairness, on the other hand, is removal of potential unfairness by taking each concrete event and the individual into consideration (Gözler, 2016). The person that will investigate this and reach the fairest solution is the judge. Distributive justice considers the personal circumstances of individuals in the distribution of rights and duties, the honors and goods they hold according to their needs (Cansel, Özel, Yüksel, $\&$ Büyüktanır, 2012). As for social justice, it is a system in which states assist citizens who are working honestly but still not generating an income sufficient to meet their certain basic needs, e.g., educational assistance, fuel allowance, and health benefits (Kaylhan, 2008: 45-46). These basic needs are met by the state today as well. Justice is an issue that has become part of social life. For example, several practices even in a family consisting of parents and children only might create the source of many conflicts that can be considered injustice (Aslan \& Şenyüz, 2017).

The significance of the justice concept has continued from the past to the present. In this context, educational institutions take on a number of tasks to help members of society to socialize, improve their social relations, and prepare themselves for social changes. The first step is the basic education, organizing learning outcomes in a manner that will help prepare children for life (Oğuz, 2013). At this stage, science of life programs and social studies programs appear in basic education. The 2009 science of life lesson curriculum aims at encouraging several personal qualities in students through experiences (MEB, 2009). One of these is the justice concept. In the updated 2017 social studies lesson curriculum, the justice concept is one of the root values to be conveyed to students during values education. Furthermore, seventh learning outcome "2.1.7. Obeys the rules of teamwork in the classroom and at school" in the "Life in Our School" unit in the second grade emphasizes the significance of the value of fairness (MEB, 2017b). The value "being fair" is included in the 2005 social studies lesson curriculum (MEB, 2005a; MEB, 2005b). In the updated 2017 social studies lesson curriculum, on the other hand, the justice concept is specified among the root values to be conveyed to students during values education (MEB, 2017a). Despite the fact that the concept of justice took place in related programs, it was seen that there was not enough work on justice. Therefore, this study aims to discover middle school students' opinions of the justice concept.

\section{Method}

For this purpose, a case study based on qualitative research methods was employed. The case study is a research method that is based on "how" and "why" questions, allowing for the investigation of a phenomenon or a fact in greater detail (Yıldırım and Şimşek, 2016: 290). The study group consists of 82 students attend in 7th grade in a middle school in the city centre of Kastamonu in the school year 2016-2017, selected according to the purposive sampling approach. Purposive sampling facilitates in-depth investigation by choosing cases rich in information regarding the aim of the study (Büyüköztürk et al., 2012: 90). Accordingly, the semi-structured interview format involves open-ended questions developed by the researcher that help reveal what people feel, why they feel it, what their emotions, attitudes and feelings are, and the factors shaping their behaviours (Ekiz, 2009: 62) were used as data collection tools. Attempts at ensuring the validity and reliability of the research were made by supporting the data obtained from students with direct written quotations from such data. The written documents obtained were analysed using content analysis. During the interpretation of the data, opinions of the students were quoted directly. Such codes as M1 (Male Participant 1) and F1 (Female Participant 1) were given to students while collecting and analysing the data.

\section{Findings}

The findings obtained from answers given by 7th-grade middle school students about the justice concept are given in tables. Answers obtained from students are represented in two different tables. In the first table, students' statements relating to the justice concept are included. The second table, on the other hand, gives place to wise sayings used by students while explaining the justice concept.

Statements of 7th grade middle school students about the justice concept are shown in Table 1. 
Table 1. Students' statements relating to the justice concept

\begin{tabular}{lcccccc}
\hline \multirow{2}{*}{ Category } & \multicolumn{2}{c}{ Gender } & \multicolumn{2}{c}{ Total } \\
& \multicolumn{2}{c}{ Female } & \multicolumn{2}{c}{ Male } & & \\
\hline Honesty and Trust & $\mathrm{f}$ & $\%$ & $\mathrm{f}$ & $\%$ & $\mathrm{f}$ & $\%$ \\
Morality & 10 & 10.99 & 3 & 3.30 & 13 & 14.28 \\
Equality & 10 & 10.99 & 5 & 5.49 & 15 & 16.48 \\
Base of the State & 16 & 17.58 & 7 & 7.69 & 23 & 25.27 \\
Abstinence from committing crimes & 19 & 20.88 & 15 & 16.48 & 34 & 37.36 \\
Legitimacy & 4 & 4.39 & 2 & 2.19 & 6 & 6.59 \\
Availability of Welfare & 23 & 25.27 & 14 & 15.38 & 37 & 40.65 \\
Legal Rules & 11 & 12.08 & 7 & 7.69 & 18 & 19.78 \\
\hline
\end{tabular}

As is seen in Table 1, 14.28\% of students explained justice as honesty and trust, $16.48 \%$ as morality, $25.27 \%$ as equality, $37.36 \%$ as survival of the state, $6.59 \%$ as abstinence from committing crimes, $40.65 \%$ as legitimacy, $19.78 \%$ availability of welfare, and $12.08 \%$ as legal rules. According to these findings, whereas a majority of students $(40.65 \%)$ explained justice as legitimacy, the number of those explaining it as abstinence from committing crimes $(6.59 \%)$ is smaller compared to other categories. When results for honesty and trust, morality, and legal rules explanations are examined, it is observed that the figures are close to each other.

When the gender variable is examined, $10.99 \%$ of female students and $3.30 \%$ of male students explained justice as honesty and trust, $10.99 \%$ of female students and $5.49 \%$ of male students as morality, $17.58 \%$ of female students and $7.69 \%$ of male students as equality, $20.88 \%$ of female students and 16.48 of male students as survival of the state, 4.39 of female students and 2.19 of male students as abstinence from committing crimes, $25.27 \%$ of female students and $15.38 \%$ of male students as legitimacy, $12.08 \%$ of female students and $7.69 \%$ of male students as availability of welfare, and $8.79 \%$ of female students and $3.30 \%$ of male students as legal rules. While a great majority of female students $(25.27 \%)$ explained justice as legitimacy, a majority of the male students $(16.48 \%)$ defined it as survival of the state. The numbers of female (4.39\%) and male students $(2.19 \%)$ explaining justice as abstinence from committing crimes are smaller when compared to other categories. Students' opinions on this topic are specified below.

M1: "A state without justice is impossible. Sense of justice is the base of the states. Where there is justice, there is a happy and free existence. Where there is no justice, on the other hand, rebellion and distress never stop."

F3: "Justice is as important and beautiful as morals. If there is no justice, then there are no morals there."

F4: "An unjust person commits crimes. But a just person defends himself, tries to be a good citizen, acts responsively and in an enlightened manner."

M7: "In a country, justice means modernity."

F8: "Justice is the base of the state. A state without justice floats in the air like an unarmoured leaf and wastes away."

F16: "When we fight with our friends at school, our teacher wants to solve the problem and listens to us. But if she defends the unjust, she will not have behaved fairly and will have done wrong to others."

M21: "Justice depends on legal rules. Obeying these rules shows the power of justice."

F30: Where there is no justice, there is no trust, and where there is no trust, there is no justice."

M38: "Legal rules help us be just. If it were not for the legal rules, everybody would act without thinking."

F40: "Justice is the base of the state. The stronger the foundation of a building is, the stronger that building is. That is, we must keep the base of the state very strong."

M47: "If there is no justice and there are no legal rules in our country, there will be no equality."

M57: "Justice is needed to distinguish the fair from the unfair."

M64: "Justice represents peace, honesty, righteousness." 
F76: "Think of a country where there is no justice, where everybody commits crimes but can wander around freely. I am sure that nobody would like to live in a state like that."

M81: "Justice is looking after people's rights."

M82: "People are born, live and die equally. A person cannot be compared with others in terms of language, religion, race and gender. Everybody is equal before the courts. And all of these rules generate justice." Wise sayings used by 7 th grade middle school students for justice concept are given in Table 2.

Table 2. Wise sayings used by students for justice concept

\begin{tabular}{lcccccc}
\hline & \multicolumn{3}{c}{ Gender } & \multicolumn{3}{c}{ Total } \\
Sayings & \multicolumn{1}{c}{ Female } & Male & \\
& f & $\%$ & f & $\%$ & f & $\%$ \\
\hline Justice can do what swords cannot do & 10 & 10.98 & 7 & 7.69 & 17 & 18.68 \\
Countries are conquered with swords but maintained with & 5 & 5.49 & 4 & 4.39 & 9 & 9.89 \\
justice. & & & & & & \\
Let justice be done upon him, even if great trouble arises. & 5 & 5.49 & 1 & 1.09 & 6 & 6.59 \\
No honour can be nobler than justice. & 2 & 2.19 & 1 & 1.09 & 3 & 3.29 \\
Where justice predominates, there is no place for guns. & 7 & 7.69 & 3 & 3.29 & 10 & 10.98 \\
Justice is the spirit of the universe. & 10 & 10.98 & 4 & 4.39 & 14 & 15.38 \\
\hline
\end{tabular}

As is seen in Table 2, the saying "Justice can do what swords cannot do" was stated by $18.68 \%$ of students, the saying "Countries are conquered with swords but maintained with justice" by $9.89 \%$, the saying "Let justice be done upon him even if great trouble arises" by $6.59 \%$, the saying "No honour can be more noble than justice" by $3.29 \%$, the saying "Where justice predominates, there is no place for guns" by $10.98 \%$, and the saying "Justice is the spirit of the universe" by $15.38 \%$. Most of the students were observed to be good at using wise sayings. It was observed that they expressed the sayings "Justice can do what swords cannot do" and "Justice is the spirit of the universe" more often.

Considering the gender variable, the saying "Justice can do what swords cannot do" was stated by $10.98 \%$ of female students and $7.69 \%$ of male students. The saying "Countries are conquered with swords but maintained with justice" was stated by $5.49 \%$ of female students and $4.39 \%$ of male students. The saying "Let justice be done upon him even if great trouble arises" was stated by $5.49 \%$ of female students and $1.09 \%$ of male students. The saying "No honour can be more noble than justice" was stated by $2.19 \%$ of female students and $1.09 \%$ of male students. The saying "Where there is justice, there is no place for guns" was stated by $7.69 \%$ of female students and $3.29 \%$ of male students. The saying "Justice is the spirit of the universe" was stated by $10.98 \%$ of female students and $4.39 \%$ of male students. While female students stated the saying "Justice is the spirit of the universe" most often (10.98\%), this saying was stated by male students less often $(4.39 \%)$. Wise sayings uttered by students on this topic are given below.

F2: "No honour can be nobler than justice. Being fair requires honesty and reliability."

F19: "Justice is the spirit of the universe. This saying means that a world without justice would rather not exist. In a universe with no justice, anything evil can happen."

M21: "A country is conquered with swords but maintained with justice. If states had not protected the lands they obtained by swords with justice, there would have been insurgencies in those states. What helps protect a state is justice."

F43: "If there is justice in a place, then no guns are needed there. This is because justice finds a solution for everything but you cannot do anything with guns."

F68: “'Justice can do what swords cannot do', said our ancestors. The Ottoman Empire managed to remain standing for six hundred years thanks to justice. It treated everyone equally and blamed nobody unjustly."

M78: "Let justice be done upon him even if great trouble arises. This saying states that justice has always been served in any case and is on the side of the right." 


\section{Conclusion and Discussion}

When the relevant literature is examined, it is seen that educational and sociological studies such as justice sentiment, social justice practices in schools and organizational justice structure take place (Örten, 2009; Uğurlu, 2009; Tomul, 2009; Aydoğmuş, 2010, Gürgen, 2017, Çinkılıç, 2017). However, there are social studies on the concept and opinions of justice in the social studies course, and teachers' studies on the perceptions of social justice and metaphorical perceptions of the middle school students regarding the concept of justice (Bursa, 2015; İnel, Urhan ve Ünal, 2017). Moreover, Au's study (2009) stated that standardized tests carried out for social justice education included in the social studies lessons are not sufficient for evaluating the subject. In short, within the scope of teaching social studies lessons, there are not enough studies about justice. This study, on the other hand, focuses on middle school students' thoughts about the justice concept.

Bursa's study (2015) stated that while social studies teachers are explaining the social justice concept, they equate equality with justice. At the same time, most social studies teachers state that social justice has an important place in social studies lessons, explaining that social studies have such goals as educating citizens, preparing individuals for life, and teaching social sciences. Still, in the study carried out by İnel, Urhan and Ünal (2017) on middle school students' justice concept, similar statements regarding the justice concept were observed. When explanations used for the metaphors formed during categorization of concepts, it became clear that $36 \%$ of students (71 students) consider the justice concept as an equality matter, 30\% of the students (60 students) as a right-law matter, $22 \%$ (44 students) as a life matter and 12\% (24 students) as a question of judgment or punishment. In this study, $14.28 \%$ of students referred to justice as honesty and trust, $16.48 \%$ as morality, $25.27 \%$ as equality, $37.36 \%$ as survival of the state, $6.59 \%$ as abstinence from committing crimes, $40.65 \%$ as legitimacy, $19.78 \%$ as availability of welfare, and $12.08 \%$ as legal rules. Studies have revealed that when explaining the justice concept, middle school students use similar concepts like equality, rights, law, etc. The concepts of equality, rights, and law very often are included within the scope of social studies lessons. These concepts emerged in the explanation of the justice concept as a result of repetition of these topics and inclusion thereof in social studies lessons. Permanence can be ensured by creating activities for other categories formed as well. Further results can be achieved about justice upon enhancement of the content thereof.

Opinions of male and female middle school students seem to be larger in number in the "Base of the State" and "Legitimacy" categories of the justice concept. This might be because these topics are treated in detail in social studies lessons. On the other hand, female and male middle school students expressed fewer opinions about the "Abstinence from committing crimes" category. The fact that crime and punishment concepts are not included within the scope of social studies lessons can be the reason why this ratio is low. Moreover, wise sayings used by students for the justice concept were revealed in this study. It was concluded that wise sayings are used more often by female students than male students. Female students can be said to be more sensitive to wise sayings. It can be concluded that social studies lessons were associated with Turkish lessons, and that wise sayings were used in order to ensure permanence. In this sense, environments in which more wise sayings are used can be provided. We can do scientific study about justice in more detail by increasing sample group.

\section{References}

Aslan, Y. İ. , Şenyüz, D. , Kortunay, A. ve Deliveli, Ö. (2011). Hukuka giriş. 6. Baskı. Bursa: Ekin Basın Yayın Dağıtım.

Aslan, Y. İ ve Şenyüz, D. (2017). Hukuka giriş. 10. Baskı. Bursa: Ekin Basın Yayın.

Atay, E.E. (2016). Hukuk başlangıcı. 3. Baskı. Ankara: Gazi Kitabevi.

$\mathrm{Au}, \mathrm{W}$. (2009). Social studies, social justice: W(h)ither the social studies in high-stakes testing?. Teacher Education Quarterlyin, 36(1). pp. 43-58. EJ851027.

Aydoğmuş, Ö. (2010). Sosyolojik açıdan "çocukta sosyal diyalog, adalet duygusu ve iktidar”. (Yayınlanmamış Yüksek Lisans Tezi), Muğla Üniversitesi, Sosyal Bilimler Enstitüsü, Muğla.

Bursa, S. (2015). Sosyal bilgiler öğretmenlerinin sosyal adalet algı ve deneyimleri. (Yayınlanmamış Yüksek Lisans Tezi), Anadolu Üniversitesi, Eğitim Bilimleri Enstitüsü, Eskişehir.

Büyüköztürk, Ş. ,Çakmak, K. E. , Akgün, Ö. E. , Karadeniz, Ş. ,Demirel, F. (2012). Bilimsel Araştırma Yöntemleri. 11. Bask1. Ankara: Pegem Akademi.

Cansel, E. , Özel, Ç. ,Yüksel, M. ve Özcan-Büyüktanır, B. (2012). Hukuka giriş. Ankara: Seçkin Yayıncılık. 
Çinkılıç, A. (2017). Örgütsel adalet algısının işkolik ve sosyal aylaklık üzerindeki etkisi: Kafkas Üniversitesi üzerine bir araştırma. (Yayınlanmamış Yüksek Lisans Tezi), Kafkas Üniversitesi, Sosyal Bilimler Enstitüsü, Kars.

Ekiz, D. (2009). Bilimsel araştırma yöntemleri. 2.Baskı. Ankara: Anı yayıncılık.

Gözler, K. (2016). Hukuka giriş. 13. Baskı. Bursa: Ekin Yayınevi.

Gürgen, B. (2017). Okullarda sosyal adalet algısının incelenmesi. (Yayınlanmamış Yüksek Lisans Tezi). Eskişehir Osmangazi Üniversitesi, Eğitim Bilimleri Enstitüsü, Eskişehir.

Güriz, A. (2012). Hukuk başlangıcı. 14. Baskı. Ankara: Siyasal Kitabevi.

İnel, Y. ,Urhan, E. ve Ünal, A. İ. (2017). Ortaokul öğrencilerinin adalet kavramına ilişkin metaforik algıları. Uluslararası Sosyal Bilgiler Eğitimi Sempozyumu VI. (USBES 2017) Sözlü Bildiri Özet Kitabı. 4-6 Mayıs 2017. Eskişehir.

Kayıhan, Ş. (2008). Hukukun temel kavramları. Ankara: Seçkin Yayınevi.

MEB (2017a). Sosyal bilgiler dersi ögretim programı (İlkokul ve Ortaokul 4, 5, 6 ve 7. Sinuflar). http://ttkb.meb.gov.tr adresinden 15.01.2017 tarihinde erişildi.

MEB (2017b). Illköğretim 1, 2 ve 3. sinuflar hayat bilgisi dersi öğretim programı ve kılavuzu. http://ttkb.meb.gov.tr adresinden 15.01.2017 tarihinde erişildi.

MEB (2009). Illköğretim 1, 2 ve 3. sinıflar hayat bilgisi dersi öğretim programı ve kılavuzu. Ankara: MEB Yayınları.

MEB (2005a). Illköğretim sosyal bilgiler dersi öğretim programı ve kılavuzu (4-5. sinıflar), Ankara: MEB Yayınları.

MEB (2005b). İlköğretim sosyal bilgiler dersi ögretim programı ve kılavuzu (6-7. sinıflar), Ankara: MEB Yayınları.

Oğuz, S. (2013). Ortaokul öğrencilerinin sosyal bilgiler eğitimi çerçevesinde hukuk okuryazarlı düzeylerinin belirlenmesi. (Yayımlanmamış Doktora Tezi). Gazi Üniversitesi, Eğitim Bilimleri Enstitüsü: Ankara.

Öktem, N. (1983). Hukuk felsefesi. İstanbul: Der Yayınları.

Örten, P. (2009). Adalet duygusu açısından iki farklı sosyo-ekonomik düzeyden çocuklar arasında bir karşılaştırma. (Yayınlanmamış Yüksek Lisans Tezi). Hacettepe Üniversitesi, Sosyal Bilimler Enstitüsü, Ankara.

Tomul, E. (2009). İlköğretim okullarındaki sosyal adalet uygulamalarına ilişkin yönetici görüşleri. Eğitim ve Bilim, 34(152), pp. 126-137.

Türk Dil Kurumu (TDK). Güncel Türkçe sözlük http://www.tdk.gov.tr/index.php?option=com_gts\&arama=gts\&guid=TDK.GTS.5ac9ce428d2f03.24870489 adresinden 01.01.2018 tarihinde erişildi.

Uğurlu, C. T. (2009). İlköğretim Okulu Öğretmenlerinin Örgütsel Bağllllk Düzeylerine Yöneticilerinin Etik Liderlik ve Örgütsel Adalet Davranışlarının etkisi. (Yayınlanmamış Doktora Tezi). İnönü Üniversitesi, Sosyal Bilimler Enstitüsü. Malatya.

Yavuz, N. ,Duman, T. ve Karakaya, N. (2016). İnsan hakları ve demokrasi-vatandaşlık bilgisi-.3. Baskı. Ankara: Pegem Akademi.

Yıldırım, A. ve Şimşek, H. (2016). Sosyal bilimlerde nitel araştırma yöntemleri. 10.Baskı. Ankara: Seçkin Yayıncilik. 